\title{
Angiotensin II AT, Receptor Blockade Ameliorates Brain Inflammation
}

\author{
Julius Benicky*,1,3, Enrique Sánchez-Lemus',3, Masaru Honda',3, Tao Pang', Martina Orecna', Juan Wang', \\ Yan Leng ${ }^{2}$, De-Maw Chuang ${ }^{2}$ and Juan M Saavedra' \\ 'Section on Pharmacology, Division of Intramural Research Programs, Department of Health and Human Services, National Institute of Mental \\ Health, National Institutes of Health, Bethesda, MD, USA; ${ }^{2}$ Molecular Neurobiology Section, Division of Intramural Research Programs, \\ Department of Health and Human Services, National Institute of Mental Health, National Institutes of Health, Bethesda, MD, USA
}

\begin{abstract}
Brain inflammation has a critical role in the pathophysiology of brain diseases of high prevalence and economic impact, such as major depression, schizophrenia, post-traumatic stress disorder, Parkinson's and Alzheimer's disease, and traumatic brain injury. Our results demonstrate that systemic administration of the centrally acting angiotensin II AT, receptor blocker (ARB) candesartan to normotensive rats decreases the acute brain inflammatory response to administration of the bacterial endotoxin lipopolysaccharide (LPS), a model of brain inflammation. The broad anti-inflammatory effects of candesartan were seen across the entire inflammatory cascade, including decreased production and release to the circulation of centrally acting proinflammatory cytokines, repression of nuclear transcription factors activation in the brain, reduction of gene expression of brain proinflammatory cytokines, cytokine and prostanoid receptors, adhesion molecules, proinflammatory inducible enzymes, and reduced microglia activation. These effects are widespread, occurring not only in well-known brain target areas for circulating proinflammatory factors and LPS, that is, hypothalamic paraventricular nucleus and the subfornical organ, but also in the prefrontal cortex, hippocampus, and amygdala. Candesartan reduced the associated anorexic effects, and ameliorated associated body weight loss and anxiety. Direct anti-inflammatory effects of candesartan were also documented in cultured rat microglia, cerebellar granule cells, and cerebral microvascular endothelial cells. ARBs are widely used in the treatment of hypertension and stroke, and their anti-inflammatory effects contribute to reduce renal and cardiac failure. Our results indicate that these compounds may offer a novel and safe therapeutic approach for the treatment of brain disorders.

Neuropsychopharmacology (20II) 36, 857-870; doi: I0.1038/npp.2010.225; published online 8 December 2010
\end{abstract}

Keywords: innate immune response; lipopolysaccharide; proinflammatory cytokines; microglia activation; sickness behavior

\section{INTRODUCTION}

Brain inflammation is an essential mechanism to restore homeostasis in response to stress, infection, or injury (Yong and Rivest, 2009). Circulating proinflammatory cytokines and hormones, bacterial endotoxins and products of neuronal injury activate transcription factors, setting in motion inflammatory cascades with participation of brain parenchymal microglia and blood-derived infiltrating macrophages (Licinio and Wong, 1997). Although a wellregulated central inflammatory reaction contributes to reestablish homeostasis, exaggerated responses lead to chronic inflammation and neuronal damage (Dantzer

\footnotetext{
*Correspondence: Dr J Benicky, Section on Pharmacology, Division of Intramural Research Programs, Department of Health and Human Services, National Institute of Mental Health, National Institutes of Health, 9000 Rockville Pike, Building 10, Room 2D57, Bethesda, MD 20892, USA, Tel: + I 301 45I-8378, Fax: + I 30I 402-0337, E-mail: benickyj@mail.nih.gov

${ }^{3}$ These authors contributed equally to this work.

Received 12 August 2010; revised 28 October 2010; accepted 12 November 2010
}

et al, 2008). Such excessive activation of immune responses increases the risk of disease in vulnerable individuals, and is an important contributing factor underlying the pathophysiology of many psychiatric and neurological diseases. These include major depression, schizophrenia, autism, post-traumatic stress disorder, and neurodegenerative disorders, such as Alzheimer's and Parkinson's disease, amyotrophic lateral sclerosis, multiple sclerosis, HIV-associated dementia, and traumatic brain injury (Fassbender et al, 2004; Hope et al, 2009; Miller et al, 2009; Rivest, 2009).

Because drugs used in peripheral inflammatory conditions are not fully effective in the brain (Nimmo and Vink, 2009), the search for novel, safe, and effective central antiinflammatory drugs is of major interest. Recent studies have focused on a neuropeptide, angiotensin II (Ang II) initially discovered as a circulating prohypertensive hormone. Ang II was later recognized as a pleiotropic factor locally formed in most tissues, including the brain (Saavedra, 1992). Most of the effects of Ang II are dependent on the stimulation of its $\mathrm{AT}_{1}$ receptors (Saavedra et al, 2006), and $\mathrm{AT}_{1}$ receptor overactivity promotes peripheral vascular and 
tissue inflammation (Savoia and Schiffrin, 2007). $\mathrm{AT}_{1}$ receptor blockers (ARBs) not only antagonize the Ang II-mediated vasoconstriction but also reverse peripheral inflammation in hypertension, atherosclerosis, and diabetes (Savoia and Schiffrin, 2007). For this reason ARBs, compounds with excellent safety margins, are commonly used not only to regulate blood pressure, but also for their capacity to protect end organs, thus decreasing heart failure and renal damage (Savoia and Schiffrin, 2007).

We previously used the centrally acting ARB candesartan (Nishimura et al, 2000), a compound blocking central $\mathrm{AT}_{1}$ receptor stimulation by Ang II when administered systemically (Seltzer et al, 2004). In spontaneously hypertensive rats (SHRs), a rodent model of genetic hypertension with overactive brain $\mathrm{AT}_{1}$ receptors, behavioral and cognitive deficits, hypersensitive to stress and to brain inflammation (Kvetnansky et al, 1979; Saavedra, 1992; Sirén et al, 1992; Russell, 2003), candesartan reversed cerebrovascular inflammation and brain ischemia (Ando et al, 2004; Zhou et al, 2005). The effects of candesartan were not restricted to hypertensive models, because the ARB also reduced strokerelated inflammation in normotensive rats (Schmerbach et al, 2008).

We hypothesized that excessive $\mathrm{AT}_{1}$ receptor activation may participate in other types of inflammatory responses in the brain, and we postulated a general anti-inflammatory effect of ARBs, unrelated to their blood pressure reducing effect. To test our hypothesis, we first selected a wellcharacterized model of inflammation, the activation of the innate immune response in the periphery and in the brain by a systemic administration of the bacterial endotoxin lipopolysaccharide (LPS) (Quan and Banks, 2007). $\mathrm{AT}_{1}$ receptor blockade significantly decreased endotoxin-induced inflammation both in vivo in peripheral tissues of normotensive rats (Sánchez-Lemus et al, 2008, 2009a,b), and in vitro in circulating monocytes from normotensive human volunteers (Larrayoz et al, 2009). These studies demonstrated that ARBs could be considered potent anti-inflammatory agents by effects unrelated to their anti-hypertensive properties.

To establish whether ARBs can exert central antiinflammatory activity, in this study we determined the effect of $\mathrm{AT}_{1}$ receptor blockade on the LPS-induced brain inflammatory response. This study extends our preliminary results reporting anti-inflammatory effects of candesartan in the cingulate cortex (Benicky et al, 2009). To investigate whether anti-inflammatory effects observed in vivo were dependent on cross-system interactions, we included in vitro assays using LPS target cells. We studied cerebellar granule cells, a highly homogeneous population of neurons (Gao et al, 1995), cerebral microvascular endothelial cells (Nakagawa et al, 2009), and cortical microglial cells (Giulian and Baker, 1986). We show here that $\mathrm{AT}_{1}$ receptor inhibition significantly and broadly decreases the brain immune response in vivo as well as the inflammatory responses in all LPS target cells studied. In addition, candesartan ameliorates LPS-induced sickness behavior, the acute anorexic effects and body weight loss (Konsman and Dantzer, 2001) and anxiety-like behavior in untreated and LPS-treated rats. These studies show that ARBs are potent central anti-inflammatory compounds, an important property of translational value.

\section{MATERIALS AND METHODS}

Detailed methods can be found in Supplementary Materials and Methods section.

\section{Animals}

Nine-week-old male Wistar Hannover (WH) rats and SHR (Taconic Farms, Germantown, NY) were used for in vivo experiments. Three-week-old male $\mathrm{WH}$ rats were used for isolation of brain microvascular endothelial cells. Eightday-old and one-day-old Sprague Dawley male and female pups (Taconic Farms) were used for isolation of cerebellar granule cells and cortical microglia, respectively. The National Institute of Mental Health Animal Care and Use Committee (Bethesda, MD) approved all procedures.

\section{In Vivo Studies}

Short-term Ang II AT $T_{1}$ receptor blockade. WH rats received daily subcutaneous injections of vehicle or candesartan (CV-11974, Astra-Zeneca, Mölndal, Sweden) at the dose of $1 \mathrm{mg} / \mathrm{kg}$ per day. This dose was similar to that used in the treatment of human cardiovascular disorders (Weinberg et al, 2004). The animals were injected intraperitoneally with $50 \mu \mathrm{g} / \mathrm{kg}$ LPS (Escherichia coli serotype 055:B5; SigmaAldrich, St Louis, MO) or saline on day 3 and were killed $3 \mathrm{~h}$ later by decapitation. Trunk blood was used for plasma preparation and brains were dissected, frozen in isopentane on dry ice, and stored at $-80{ }^{\circ} \mathrm{C}$ until used.

Behavioral studies. For anorexia determination, separate groups of individually housed $\mathrm{WH}$ rats were subjected to short-term Ang II $\mathrm{AT}_{1}$ receptor blockade followed by intraperitoneal injection of $50 \mu \mathrm{g} / \mathrm{kg}$ LPS as described above. Animals were euthanized 2 days after LPS injection. Body weight and food consumption were monitored daily for the duration of experiment. For anxiety determination, SHR were treated as above. At $3 \mathrm{~h}$ after LPS injection, the rats were tested on an elevated plus maze as described previously (Saavedra et al, 2006). The time spent and the number of entries into the open and closed arms were recorded during $5 \mathrm{~min}$.

Sustained Ang II AT $T_{1}$ receptor blockade. WH rats were implanted subcutaneously with osmotic minipumps (model 2002, Alza Scientific Products, Palo Alto, CA) containing candesartan $(1 \mathrm{mg} / \mathrm{kg}$ per day) or vehicle. On day 14 , the animals were injected intraperitoneally with $50 \mu \mathrm{g} / \mathrm{kg}$ LPS or saline and were killed $3 \mathrm{~h}$ later by decapitation. Trunk blood was used for plasma preparation and brains were dissected, frozen in isopentane on dry ice and stored at $-80{ }^{\circ} \mathrm{C}$ until used. For immunohistochemical studies, separate groups of animals treated as above were anesthetized $3 \mathrm{~h}$ after LPS or saline injection and transcardially perfused with $4 \%$ buffered formaldehyde. The brains were dissected, post-fixed overnight, cryoprotected by $30 \%$ sucrose, frozen in isopentane on dry ice, and stored at $-80{ }^{\circ} \mathrm{C}$ until used.

\section{In Vitro Studies}

Cerebellar granule cell culture. Cells were isolated from 8-day-old rat pups as described previously (Gao et al, 1995). 
The isolated cells were plated at a density of $1.2 \times 10^{6}$ cells $/ \mathrm{ml}$ and cultured for 6-14 days. Before the experiment, the cells were starved overnight in plain medium and subsequently treated for $4 \mathrm{~h}$ with $500 \mathrm{ng} / \mathrm{ml}$ LPS with or without $2 \mathrm{~h}$ pretreatment with $5 \mu \mathrm{M}$ candesartan. The dose of candesartan used was similar to those necessary to reduce Ang II effects in cell cultures (Seeger et al, 2001). Medium was saved and cells were lysed for RNA isolation as described below.

Brain microvascular endothelial cell culture. Cultures were prepared as described previously (Nakagawa et al, 2009). The cells were used after the first passage when they reached $80 \%$ confluence. Before the experiment, cells were starved overnight in a serum-free medium followed by treatment with $100 \mathrm{ng} / \mathrm{ml}$ LPS for $4 \mathrm{~h}$ with or without $2 \mathrm{~h}$ pre-incubation with $10 \mu \mathrm{M}$ candesartan. Medium was saved and cells were lysed for RNA isolation as described below.

Cortical microglia cell culture. Cultures were prepared as described (Giulian and Baker, 1986). Initially prepared mixed glial cells were cultured for 10 days and subsequently used for microglia preparation. Purified microglial cells were allowed to grow for $24 \mathrm{~h}$, starved overnight in a serum-free medium, and subsequently treated for $4 \mathrm{~h}$ with $100 \mathrm{ng} / \mathrm{ml}$ LPS with or without $2 \mathrm{~h}$ pre-incubation with $10 \mu \mathrm{M}$ candesartan. Medium was saved and cells were lysed for RNA isolation as described below.

\section{Determination of Cytokine Levels}

Cytokines in plasma and medium were measured by commercial enzyme-linked immunosorbent assay kits from BioSource (Camarillo, CA) for interleukin 6 (IL-6) and tumor necrosis factor- $\alpha$ (TNF- $\alpha$ ), and from R\&D Systems (Minneapolis, MN) for IL-1 $\beta$ and IL-10.

\section{Microdissection of Brain Structures}

Coronal sections $(300 \mu \mathrm{m})$ of fresh-frozen brains were cut on a cryostat, mounted on slides, and used for punch microdissection as follows (positions are relative to bregma): three sections between -1.3 and $-2.2 \mathrm{~mm}$ for the paraventricular nucleus (PVN) and the central nucleus of the amygdala; two sections between -0.7 and $-1.3 \mathrm{~mm}$ for the subfornical organ (SFO); three sections between -2.2 and $-3.1 \mathrm{~mm}$ for the CA1 subdivision of the hippocampus; and three sections between 3.7 and $2.9 \mathrm{~mm}$ for the ventromedial prefrontal cortex (Paxinos and Watson, 1998). Punch microdissection was performed under stereomicroscope control using Harris Uni-Core microdissection needles of $0.75 \mathrm{~mm}$ diameter for the PVN and $1 \mathrm{~mm}$ for other brain structures. The individual punches dissected from the same nucleus were pooled and immediately homogenized for RNA isolation as described below. Tissues from each rat were studied individually.

\section{Determination of mRNA Expression By Real-Time PCR}

RNA was isolated by TRIzol reagent (Invitrogen, Carlsbad, $\mathrm{CA}$ ) and purified using the RNeasy Mini kit (Qiagen, Valencia, CA). Total RNA $(0.15 \mu \mathrm{g}$ from brain tissue; $1 \mu \mathrm{g}$ from cell lysates) was reversely transcribed into cDNA and quantified by real-time PCR as previously described (Sánchez-Lemus et al, 2009b). Primers used in the study are listed in Supplementary Table S1. Target cDNA from individual samples was normalized to GAPDH mRNA and expressed as a fold change relative to the vehicle-saline group.

\section{Ang II Receptor Autoradiography}

Binding of $\left[{ }^{125} \mathrm{I}\right]$ Sarcosine ${ }^{1}$-Ang II (ARC, St Louis, MO) to $16 \mu \mathrm{m}$ coronal sections of fresh frozen brains was performed as described previously (Tsutsumi and Saavedra, 1991).

\section{Localization and Quantification of mRNA Expression By In Situ Hybridization}

Coronal sections $(16 \mu \mathrm{m})$ of fresh frozen brains were cut on a cryostat, mounted on positively charged slides, dried for $5 \mathrm{~min}$ at $50^{\circ} \mathrm{C}$, and stored at $-80^{\circ} \mathrm{C}$ until used. In situ hybridization of $\mathrm{AT}_{1 \mathrm{~A}}$ receptor mRNA was performed using $\left[{ }^{35} \mathrm{~S}\right.$-labeled antisense and sense riboprobes corresponding to the $368 \mathrm{bp}$ Pall fragment from the $3^{\prime}$-noncoding region of the rat $\mathrm{AT}_{1 \mathrm{~A}} \mathrm{CDNA}$ as described previously (Jöhren et al, 1995).

In situ hybridization of c-Fos and IL- $1 \beta$ mRNA was performed using $\left[{ }^{35} \mathrm{~S}\right]$-labeled oligonucleotide probes. Antisense probes for the rat IL- $1 \beta, 5^{\prime}$-CCACGGGCAAGACA TAG GTAGCTGCCACAGCTTCTCCACAGCCAC-3' (Kim et al, 2004), and c-Fos, 5'-GCAGCGG GAGGATGACGCCTC GTAGTCCGCGTTGAAACCCGAGAA-3' (Vaisanen et al, 2004), and their corresponding sense probes were $3^{\prime}$ labeled with $\left[\alpha-{ }^{35}\right.$ S $]$-ATP (NEN/Perkin Elmer, Waltham, MA) to a specific activity of $3-4 \times 10^{8}$ c.p.m./ $/ \mu$ g. The sections were fixed in $4 \%$ formaldehyde, acetylated, delipidated, and exposed to hybridization buffer containing $2 \times 10^{7}$ c.p.m./ml sense or antisense probe. After hybridization for $18 \mathrm{~h}$ at $40{ }^{\circ} \mathrm{C}$, the sections were washed, dehydrated, and exposed to Biomax MR film. The optical densities of autoradiograms were quantified by comparison with $\left[{ }^{14} \mathrm{C}\right]$-microscale standards (Tsutsumi and Saavedra, 1991) and expressed as $\mathrm{nCi} / \mathrm{g}$ tissue.

\section{Immunohistochemical Localization and Quantification of c-Fos and Microglia}

Coronal sections $(16 \mu \mathrm{m})$ from fixed brains were cut on a cryostat, mounted to positively charged slides, vacuumdried, and stored at $-80^{\circ} \mathrm{C}$ until used. The sections were immersed into ice-cold acetone for $15 \mathrm{~min}$, air dried, and pre-incubated $3 \times 5 \mathrm{~min}$ in Tris-buffered saline $(20 \mathrm{mM}$ Tris, $136 \mathrm{mM} \mathrm{NaCl}, \mathrm{pH} 7.4$ ) containing $0.2 \%$ Triton X-100. After quenching of intracellular peroxidase and blocking of endogenous biotin, the sections were blocked with $10 \%$ of normal goat serum and exposed to primary antibody overnight at $4{ }^{\circ} \mathrm{C}$. Rabbit polyclonal antibody against rat c-Fos (Ab-5, 1:10 000, Calbiochem, La Jolla, CA), or mouse monoclonal antibody against rat $\mathrm{CD} 11 \mathrm{~b} / \mathrm{c}(\mathrm{Ox}-42,1: 300$, BD Pharmingen, San Jose, CA) were used as primary antibodies. After washing, the sections were exposed to goat biotin-conjugated antibody against rabbit or mouse IgG (1:1000, Jackson ImmunoResearch, West Grove, PA) followed by incubation with avidin and biotin-conjugated horseradish 
peroxidase $\mathrm{H}$. The sections were exposed to $\mathrm{DAB}$ reagent (Vector Laboratories, Burlingame, CA), counter-stained with hematoxylin, dehydrated in ethanol, cleared with xylene, and coverslipped with mounting medium.

Data acquisition and quantification. For data acquisition and quantification, sections were examined by an investigator blinded to the protocol used and the identity of the slides. Images were acquired by Axiocam digital camera (Zeiss, Jena, Germany) connected to a Zeiss Axioskop light microscope under constant illumination. Images were processed and analyzed using Image J software (Ruifrok and Johnston, 2001). Induction of c-Fos protein was expressed as the number of c-Fos-positive cells per PVN section. Microglia activation was expressed as a proportion of Ox-42-positive area to the total area of the PVN. The increase in the proportion of the area occupied by microglia was used as a measure of activation (Milligan et al, 1991; Popovich et al, 1997).

\section{Statistical Analysis}

Results are expressed as means \pm SEM for groups of 5-10 animals measured individually. Results from cell culture experiments are expressed as means \pm SEM of three independent cell preparations. To address the differences among all individual groups, we analyzed the data by oneway ANOVA followed by the post hoc Newman-Keuls' test for all determinations with significant omnibus ANOVA. Differences were considered significant at $P<0.05$.

\section{RESULTS}

Effects of LPS and an ARB on brain Ang II $\mathrm{AT}_{1 \mathrm{~A}}$ mRNA expression and $\mathrm{AT}_{1}$ receptor binding. When rats were studied at $3 \mathrm{~h}$ after LPS administration, the endotoxin upregulated $\mathrm{AT}_{1 \mathrm{~A}}$ receptor mRNA expression in the hypothalamic PVN but not in the SFO, and did not alter $\mathrm{AT}_{1}$ receptor binding in either structure (Supplementary Figure S1). Candesartan significantly blocked $\mathrm{AT}_{1}$ receptor binding in the PVN and SFO in both vehicle- and in LPStreated rats (Supplementary Figure S1).

\section{Ang II $\mathrm{AT}_{1}$ Receptor Blockade Decreases LPS-Induced Release of Proinflammatory Cytokines to the Circulation}

The basal cytokine levels in plasma were below the limit of detection in vehicle-saline control rats and were not changed by $\mathrm{AT}_{1}$ receptor blockade (Figure 1). LPS markedly elevated plasma levels of the proinflammatory cytokines TNF- $\alpha$, IL- 6 and IL- $1 \beta$, and the anti-inflammatory cytokine IL-10 (Figure 1). Both short term and sustained $\mathrm{AT}_{1}$ receptor blockade significantly reduced LPS-induced plasma levels of proinflammatory cytokines, but did not affect IL-10 concentrations (Figure 1).

\section{Ang II $\mathrm{AT}_{1}$ Receptor Blockade Reduces LPS-Induced Proinflammatory Cytokine mRNA in the Brain}

LPS produced a widespread increase in TNF- $\alpha$, IL- $1 \beta$, and IL-6 mRNA expression in the PVN, SFO, ventromedial prefrontal cortex, central nucleus of the amygdala, and the CA1 subdivision of the hippocampus (Figure 2). The effects of LPS were significantly reduced by short-term $\mathrm{AT}_{1}$ receptor blockade in all areas examined (Figure 2).
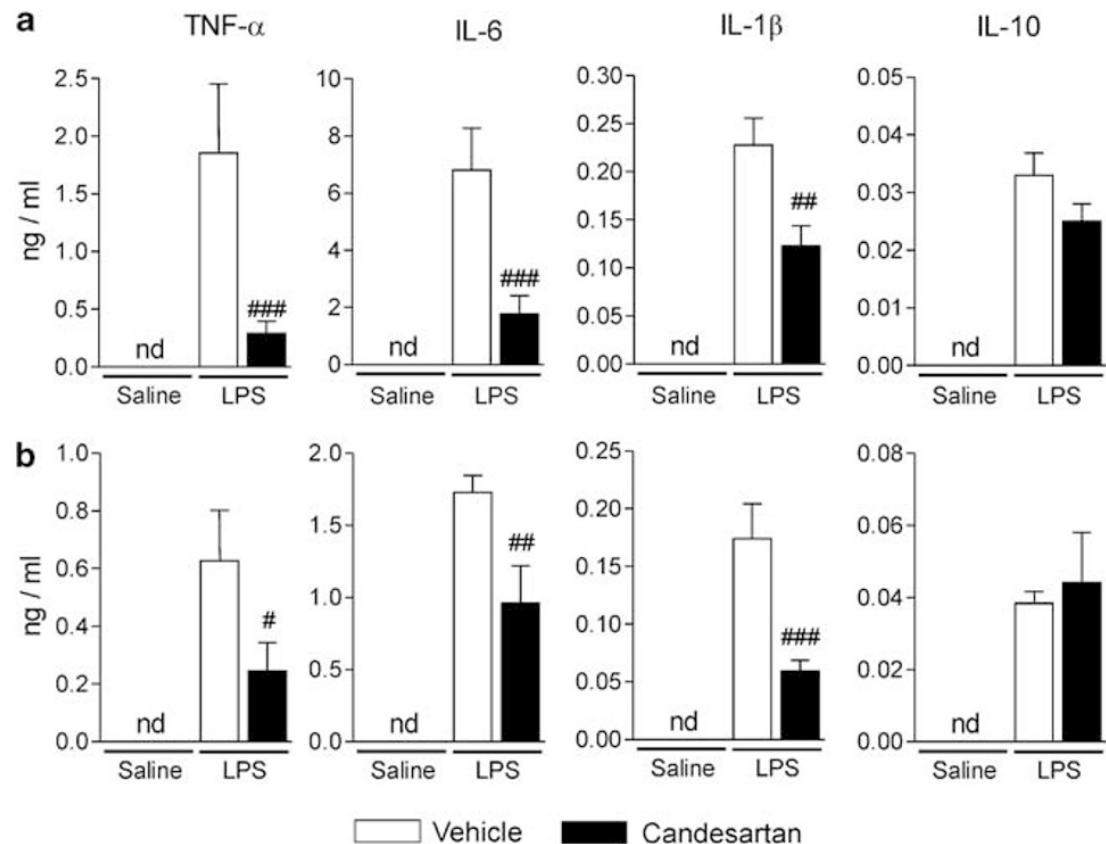

Figure I Selective decrease of LPS-induced proinflammatory cytokine release to the circulation by angiotensin II AT, receptor blockade. Short-term (a) and sustained (b) candesartan treatments were followed by LPS or saline injection as described in Materials and Methods. The levels of cytokines in plasma $3 \mathrm{~h}$ after LPS or saline injection were detected by specific ELISA. Data are expressed as means $\pm \operatorname{SEM}(n=5-16)$. ${ }^{\#} P<0.05,{ }^{\# \#} P<0.01,{ }^{\# \#} P<0.001$ compared with vehicle-LPS group; nd, non-detectable. 


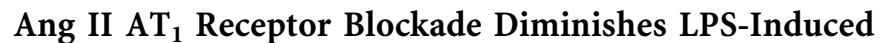
mRNA Expression of Brain Proinflammatory Factors

Short-term candesartan pretreatment significantly reduced LPS-induced increase in mRNA expression of multiple proinflammatory factors in the PVN and the SFO (Figure 3 and Supplementary Figure S2). These include: (a) the LPS recognition molecule CD14; (b) the immediate early genes c-Fos and FosB, and the inhibitor of $\kappa \mathrm{B}(\mathrm{I} \kappa \mathrm{B}-\alpha)$, representing the activation of the nuclear factor- $\kappa \mathrm{B}$ (NF- $\kappa \mathrm{B})$; (c) inflammatory factor receptors, TNF- $\alpha$ R1, TNF- $\alpha$ R2, IL-1 R1, IL-6R, the IL-1R antagonist, and the prostaglandin $\mathrm{E}_{2}\left(\mathrm{PGE}_{2}\right)$

Ventromedial prefrontal cortex

Bregma $3.2 \mathrm{~mm}$
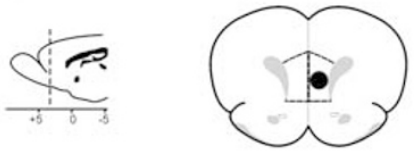

Subfornical Organ

Bregma $-0.9 \mathrm{~mm}$
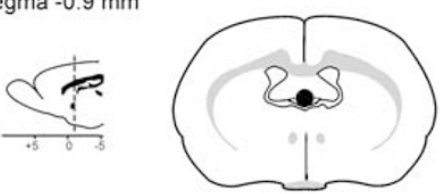

Paraventricular nucleus

Bregma $-1.8 \mathrm{~mm}$
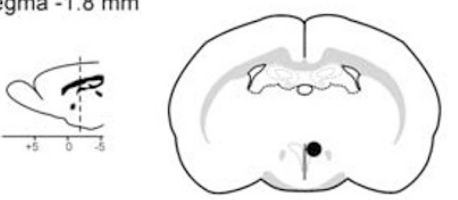

Central nucleus of the amygdala

Bregma - $1.8 \mathrm{~mm}$
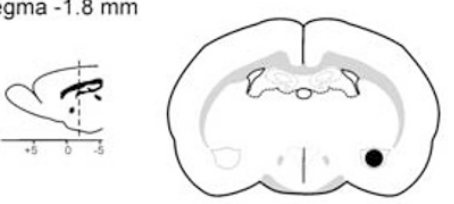

Hippocampus CA1

Bregma $-2.8 \mathrm{~mm}$

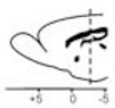

TNF $-\alpha$

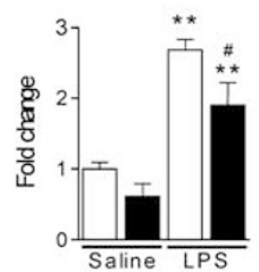

TNF- $\alpha$

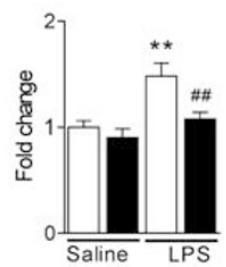

TNF- $\alpha$

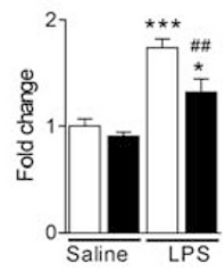

TNF- $\alpha$

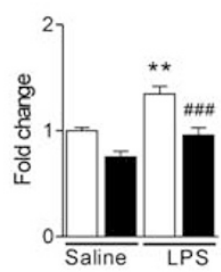

TNF- $\alpha$

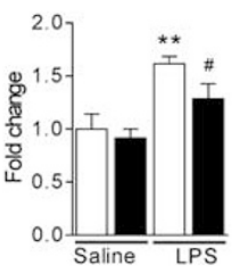

IL-6

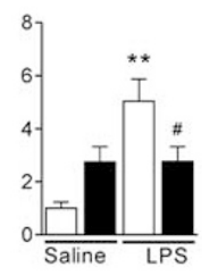

IL-6

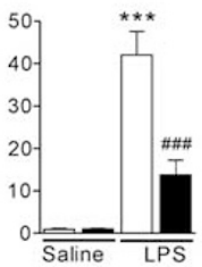

IL-6

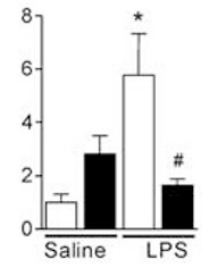

IL-6

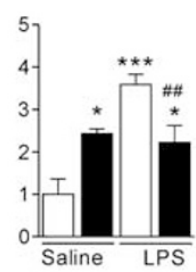

IL-6

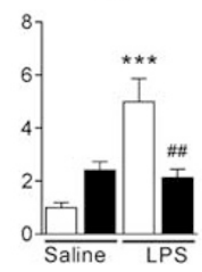

IL-1 $\beta$

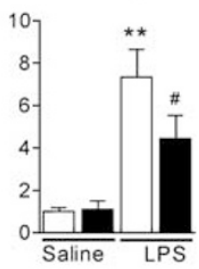

IL-1 $\beta$

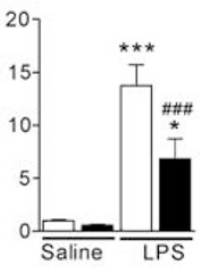

IL-1 $\beta$

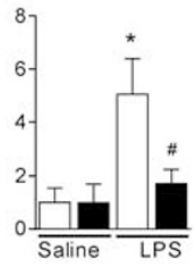

IL-1 $\beta$

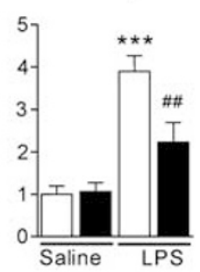

IL-1 $\beta$

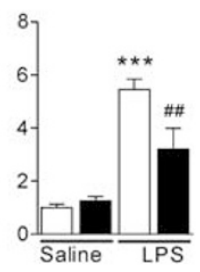

Vehicle

Figure 2 Widespread decrease of LPS-induced proinflammatory cytokine mRNA expression in brain by angiotensin II AT, receptor blockade. Short-term treatment with candesartan was followed by LPS injection as described in Materials and Methods. Expression of mRNAs of proinflammatory cytokines was detected by real-time PCR in brain structures isolated by punch microdissection from $300 \mu \mathrm{m}$ coronal brain sections. The scheme on the left illustrates the distance from bregma and the punch area (black circle) in the corresponding coronal sections. The expression of all genes was normalized to the level of GAPDH mRNA. Data are expressed as a fold change relative to vehicle-saline group. Data represent mean $\pm S E M(n=5-8)$. * $P<0.05$, $* * P<0.01$,

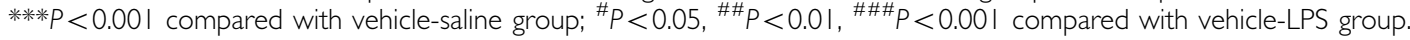


receptor EP4; (d) the nitric oxide (NO)-producing isoenzyme inducible $\mathrm{NO}$ synthase (iNOS) and the $\mathrm{PGE}_{2}$-producing enzyme cyclooxygenase 2 (COX-2); (e) the adhesion molecules intercellular adhesion molecule-1 (ICAM-1) and the vascular cell adhesion molecule-1 (VCAM-1); and (f) the microglia activation marker CD40 (Figure 3 and Supplementary Figure S2). For the most part, the responses to LPS and $\mathrm{AT}_{1}$ receptor blockade were similar in the PVN and SFO, with the ARB significantly decreasing expression of LPS-induced inflammatory factor mRNA expression. A few exceptions are noted in Supplementary Figure S2.

Sustained candesartan pretreatment yielded results similar to those obtained with short-term pretreatment for all factors examined in the PVN (Supplementary Figure S3). In addition, LPS upregulated, and short-term candesartan treatment prevented, c-Fos mRNA in the PVN, SFO, and choroid plexus, and IL-1 $\beta$ mRNA in the SFO and choroid plexus visualized by in situ hybridization. IL-1 $\beta$ mRNA was not detected in the PVN (Figure 4a-d).

\section{Ang II AT 1 Receptor Blockade Lessens LPS-Induced} c-Fos Protein Expression and Microglia Activation

Long-term ARB pretreatment suppressed, in the PVN, LPS-induced increase in the number of cells expressing c-Fos (Figure 5a and c) and microglial activation detected by OX-42 immunostaining (Figure $5 \mathrm{~b}$ and $\mathrm{d}$ ).

\section{$\mathrm{AT}_{1}$ Receptor Blockade Decreases LPS-Induced} Stimulation of Proinflammatory Factors in Cultured Cerebellar Granule Cells

In primary cultures of cerebellar granule cells, candesartan suppressed LPS-induced upregulation of TNF- $\alpha$, IL- $1 \beta$, and
IL-6, $\mathrm{AT}_{1 \mathrm{~A}}$ receptor, $\mathrm{CD} 14$, and $\mathrm{I} \kappa \mathrm{B}-\alpha$ mRNA (Figure $6 \mathrm{a}$ ). LPS elicited an $\sim 100$-fold increase in TNF- $\alpha$ release into the cultured medium, dose dependently inhibited by candesar$\tan$ (Figure 6a).

LPS Increases $\mathrm{AT}_{1 \mathrm{~A}}$ Receptor Transcription and $\mathrm{AT}_{1}$ Receptor Blockade Diminishes LPS-Induced iNOS and Cytokine Expression in Cultured Cerebral Microvascular Endothelial Cells

In primary cultures of rat cerebrovascular endothelial cells, LPS induced expression of $\mathrm{AT}_{1 \mathrm{~A}}$ receptor mRNA (Figure 6b). Incubation in the presence of candesartan decreased the LPS-induced expression of TNF- $\alpha$, IL- $1 \beta$, and iNOS mRNA (Figure 6b).

\section{$\mathrm{AT}_{1}$ Receptor Blockade Decreases LPS-Induced Stimulation of Proinflammatory Factors in Cultured Microglial Cells}

In primary cultures of cortical microglia, candesartan reduced LPS-induced upregulation of IL-1 $\beta$ and CD40 mRNA (Figure $6 c$ ). LPS induced $\sim 20$-fold increase in IL- $1 \beta$ release into the cultured medium; the effect that was significantly reduced by candesartan (Figure 6c).

\section{$\mathrm{AT}_{1}$ Receptor Blockade Reduces the Acute LPS-Induced Anorexic Effect and Body Weight Loss}

Administration of LPS produced an acute anorexic effect and decrease in body weight (Figure 7a). These effects were significantly reduced by $\mathrm{AT}_{1}$ receptor blockade (Figure $7 \mathrm{a}$ ).

\section{Paraventricular nucleus}
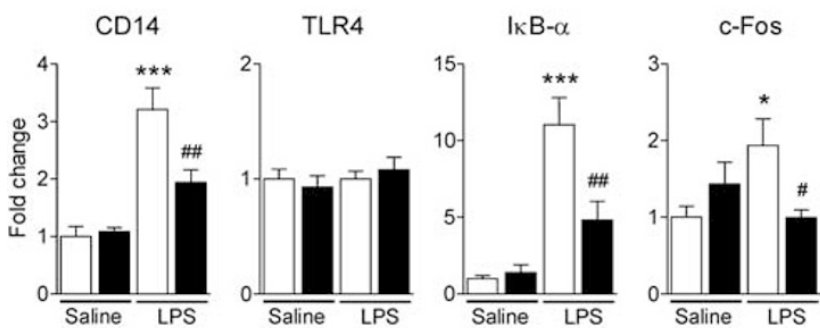

iNOS

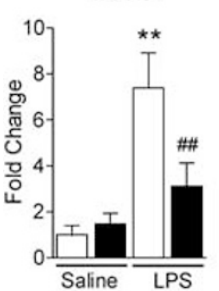

cox-2
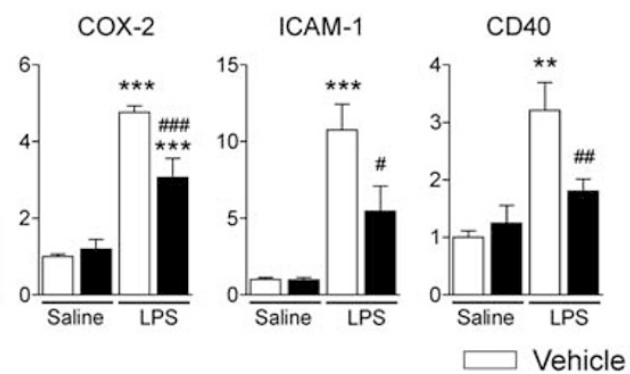

\section{Subfornical organ}
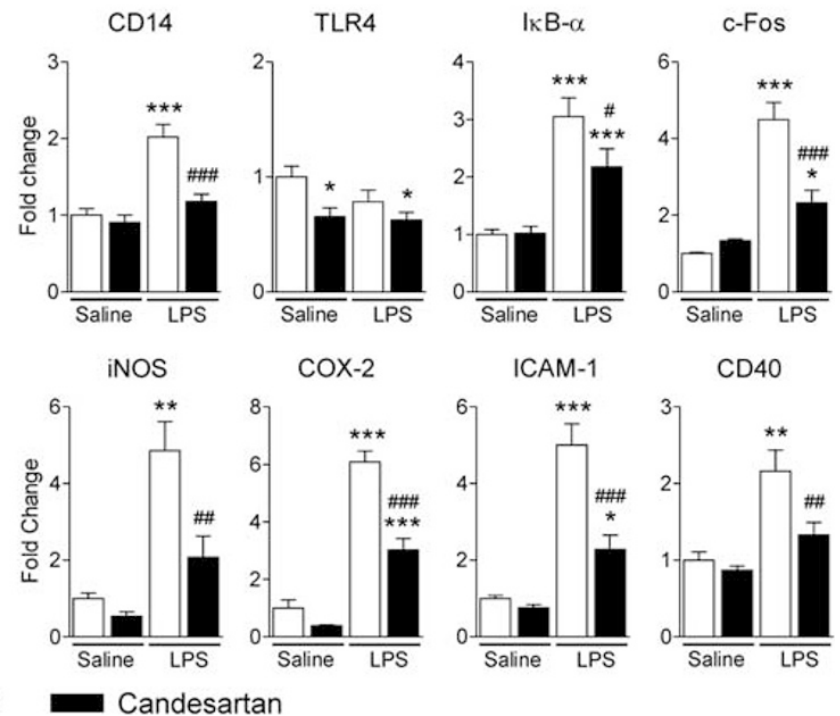

Figure 3 Decrease of LPS-induced inflammatory factor mRNA expression in PVN and SFO by angiotensin II AT, receptor blockade. Short-term candesartan treatment was followed by LPS injection as described in Materials and Methods. Expression of mRNAs of proinflammatory factors and mediators was detected in microdissected PVN and SFO by real-time PCR and was normalized to the level of GAPDH mRNA. Results are expressed as a fold change relative to vehicle-saline group. Data represent mean \pm SEM $(n=5-8)$. $* P<0.05$, $* * P<0.01$, **** $P<0.00$ I, compared with vehicle-saline group; ${ }^{\#} P<0.05,{ }^{\# \#} P<0.01,{ }^{\#} P<0.001$, compared with vehicle-LPS group. 
a

Vehicle-

Saline

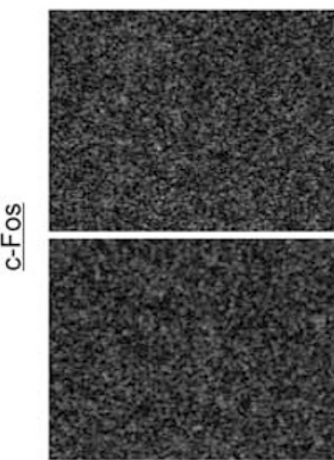

CandesartanSaline

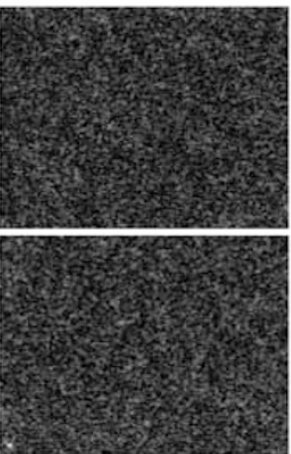

VehicleLPS

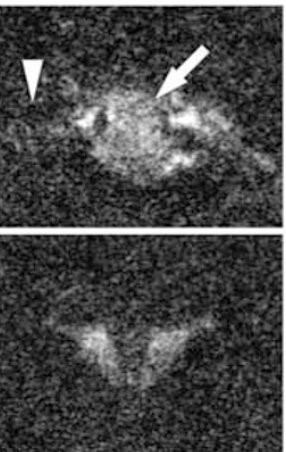

Candesartan-

LPS

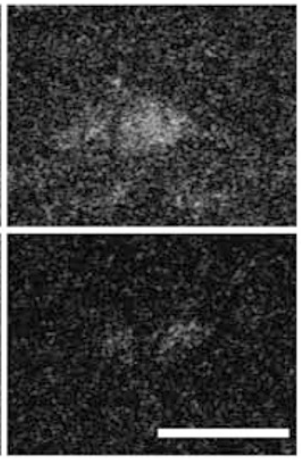

PVN b

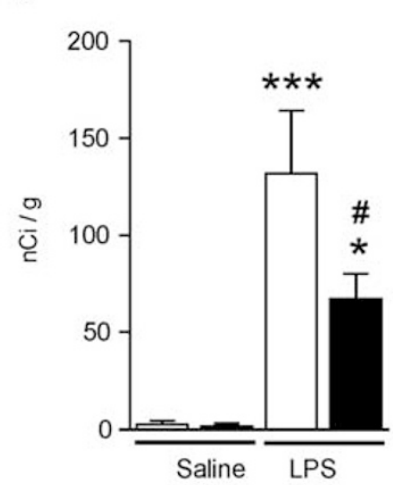

Choroid Plexus

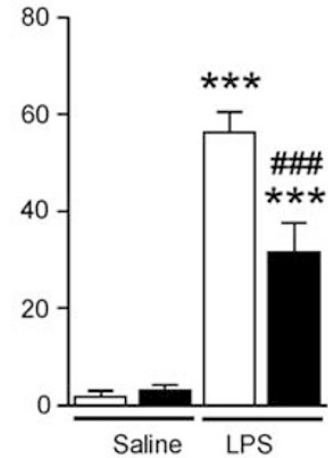

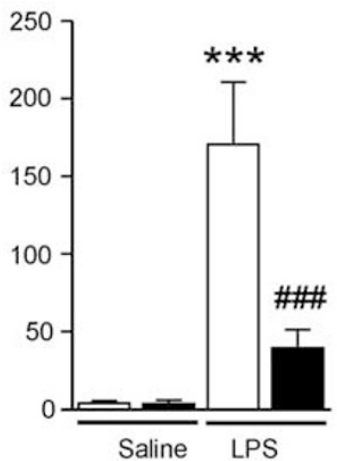

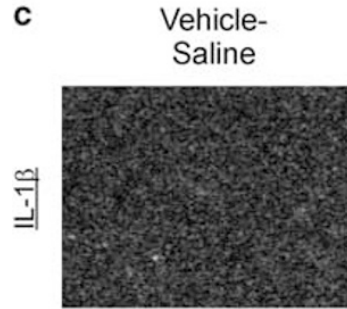

Candesartan-

Saline

Vehicle-

LPS

Candesartan-
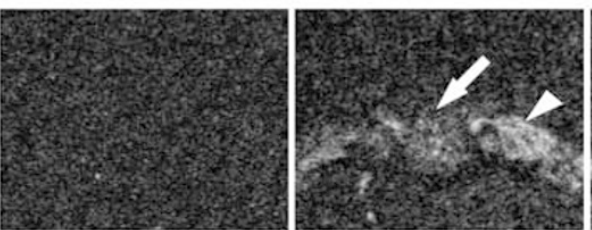

LPS

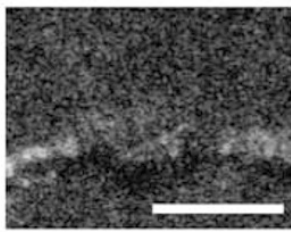

d

SFO

Choroid Plexus
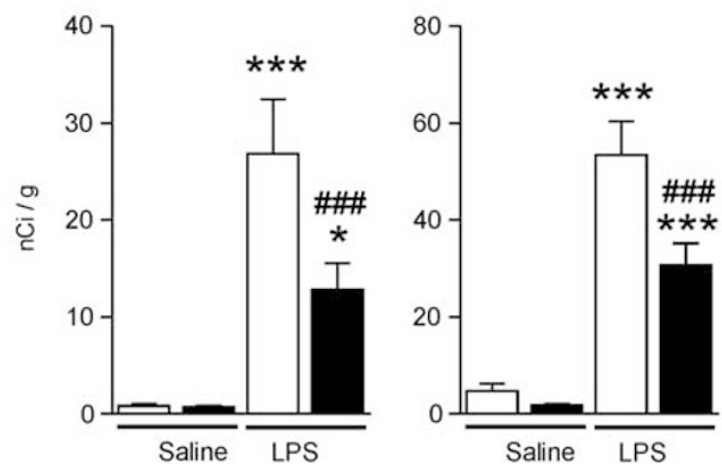

Vehicle

Candesartan

Figure 4 Angiotensin II AT, receptor blockade attenuates LPS-induced expression of c-Fos mRNA in PVN, SFO, and choroid plexus and IL- I $\beta$ mRNA in SFO and choroid plexus. Short-term candesartan and LPS were administered as described in Materials and Methods. Expression of c-Fos and IL-I $\beta$ mRNAs was analyzed by in situ hybridization (a) Representative dark field images of film autoradiograms illustrating the expression of c-Fos mRNA in SFO (top) and PVN (bottom). (b) Quantitative analysis of c-Fos mRNA in SFO and PVN. (c) Representative dark field images of film autoradiograms illustrating the expression of IL-I $\beta$ mRNA in SFO and choroid plexus. (d) Quantitative analysis of IL-I $\beta$ mRNA in SFO and choroid plexus. Data are expressed as

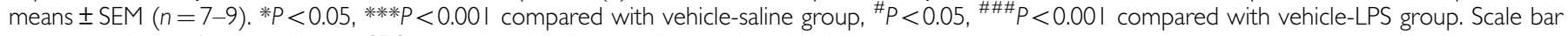
represents $1 \mathrm{~mm}$. Arrow points to SFO; arrowhead indicates adjacent choroid plexus. 

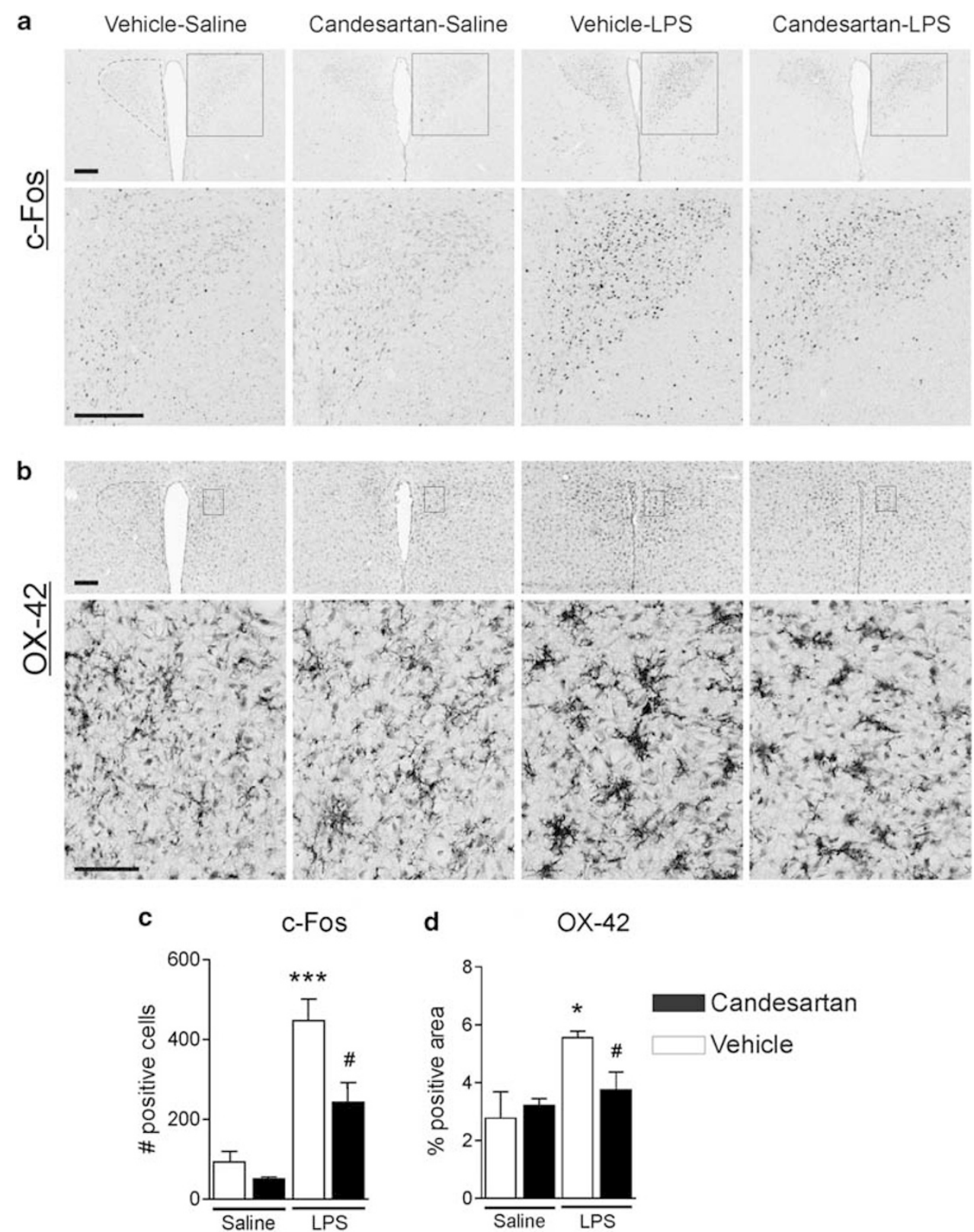

Figure 5 Angiotensin II AT, receptor blockade suppresses LPS-stimulated c-Fos induction and microglia activation in the PVN. Rats were treated with candesartan for 2 weeks followed by LPS administration as described in Materials and Methods. (a) Representative photomicrographs of c-Fos immunoreactivity in PVN. Rectangle area on the top image is magnified in the image below. Scale bar represents $200 \mu \mathrm{m}$. Dashed line outlines the area of PVN. (c) Quantitative analysis of c-Fos immunoreactivity in the PVN. Results are expressed as a number of c-Fos-positive cells per PVN section. (b) Representative photomicrographs of microglia in PVN stained with OX-42 antibody. Dashed line in the upper image outlines the area of PVN. Rectangle area in the upper image is magnified below. Scale bars represent $200 \mu \mathrm{m}$ in the upper image and $50 \mu \mathrm{m}$ in the lower image. (d) Quantitative analysis of microglia activation in PVN. An increase in the proportion of area positively stained with OX-42 antibody was used as a measure of microglia activation and is expressed as a percent of total area of PVN per section. Data are shown as means \pm SEM $(n=5-8)$. $* P<0.05$, **** $P<0.00$ I compared with vehicle-saline group; ${ }^{\#} P<0.05$ compared with vehicle-LPS group.

\section{$\mathrm{AT}_{1}$ Receptor Blockade Ameliorates Anxiety in SHR}

Anxiety-like behavior was determined by testing on an elevated plus maze. The time spent in the open arms and the number of entries into the open arms were not significantly affected by candesartan pre-treatment, although the consistent tendency toward the higher scores in the candesartan-treated groups was observed in both parameters (Figure $7 \mathrm{~b}$ ). The proportion of the open arm entries relative to the total number of entries was significantly increased by candesartan (Figure 7b) indicative of reduced anxiety.

\section{DISCUSSION}

Our results demonstrate widespread anti-inflammatory effects of Ang II $\mathrm{AT}_{1}$ receptor blockade in the periphery and brain. Blockade of brain $\mathrm{AT}_{1}$ receptors was achieved by 
a
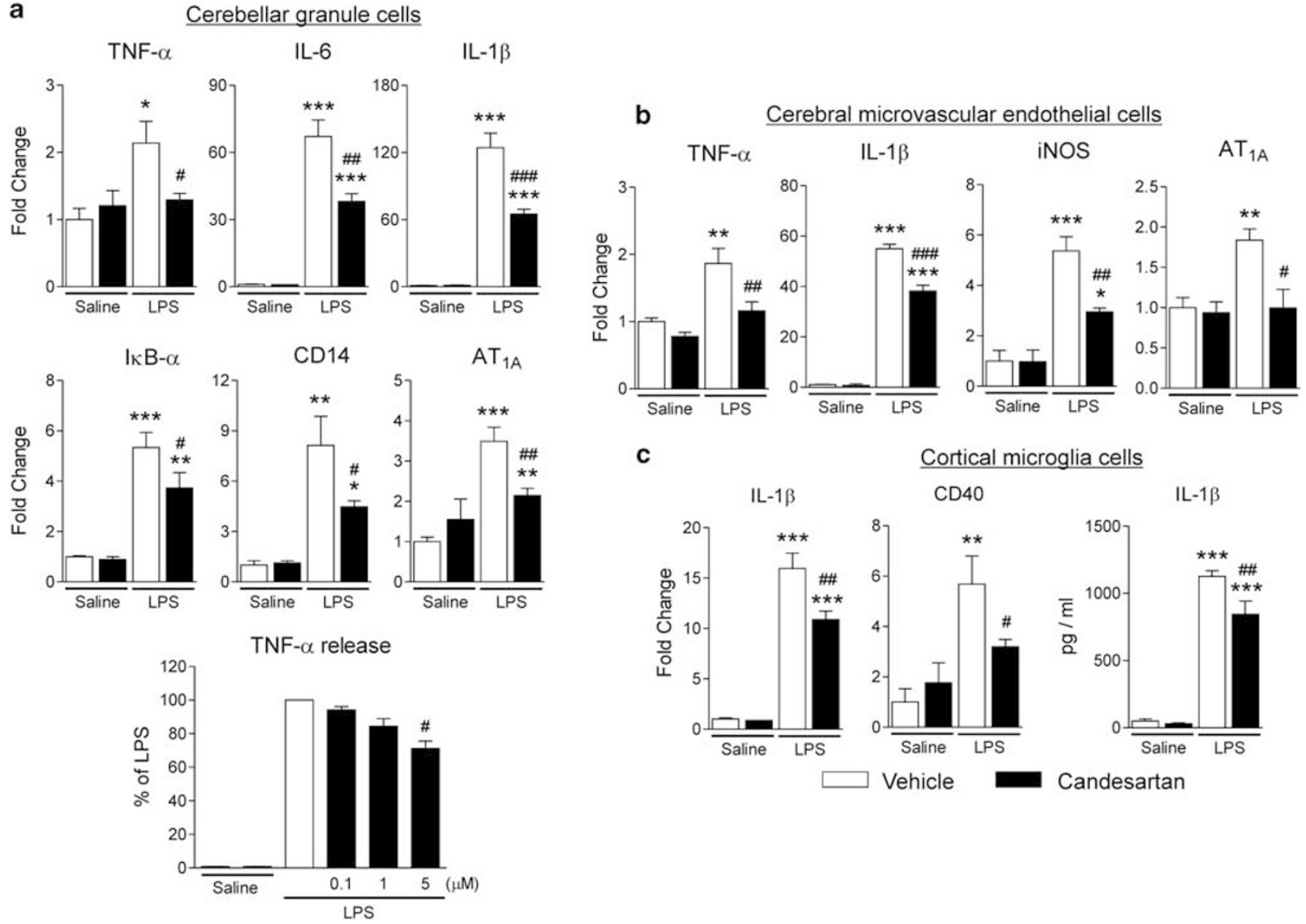

C

Cortical microglia cells

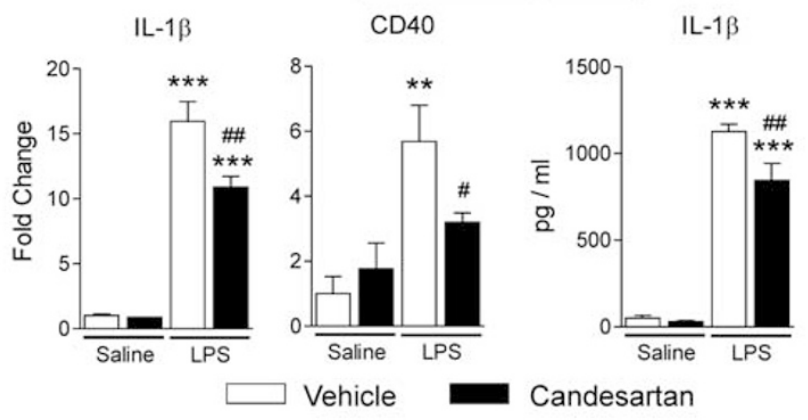

Figure 6 Angiotensin II AT, receptor blockade decreases LPS-induced inflammation markers in cerebellar granule cells (a), cerebral microvascular endothelial cells (b) and cortical microglia in culture (c). Cells were isolated and cultured as described in Materials and Methods. Expression of mRNAs was detected by real-time PCR and normalized to the level of GAPDH mRNA. Results are expressed as a fold change relative to vehicle-saline group. The release of TNF- $\alpha$ and IL- I $\beta$ was determined by ELISA in the incubation media as described in Materials and Methods. Data are presented as means \pm SEM of three independent experiments performed in duplicates. ${ }^{*} P<0.05$, ${ }^{*} * P<0.0$ I, ${ }^{* * *} P<0.00$ I compared with vehicle-saline group; ${ }^{\#} P<0.05$, ${ }^{\# \#} P<0.0$ I, $\# \#$ \# $<0.00$ I compared with vehicle-LPS group.

systemic administration of candesartan, an ARB with central $\mathrm{AT}_{1}$ receptor blocking activity (present results; Nishimura et al, 2000; Sánchez-Lemus et al, 2009b) administered at a dose without major effects on systolic blood pressure in normotensive rats (Sánchez-Lemus et al, 2008). At this dose, candesartan prevented the consequences of not only of peripheral but also central Ang II-induced $\mathrm{AT}_{1}$ receptor stimulation (Seltzer et al, 2004). The anti-inflammatory effects of $\mathrm{AT}_{1}$ receptor blockade occurred both after short-term and sustained ARB pretreatment, indicating that the effects are not lost over time. At the early time point studied, LPS enhanced $\mathrm{AT}_{1 \mathrm{~A}}$ receptor transcription in the PVN but not in the SFO (present results; Sánchez-Lemus et al, 2009b) and in cultured cerebral microvascular endothelial and cerebellar granule cells.

$\mathrm{AT}_{1}$ receptor blockade reduced, as a consequence of effects on peripheral macrophages (Sánchez-Lemus et al, 2008, 2009a,b), the acute induction and release to the circulation of the major proinflammatory cytokines with direct actions in the brain without changing levels of the anti-inflammatory cytokine IL-10 (Maynard and Weaver, 2008). Candesartan decreased the LPS-induced formation and release of the proinflammatory hormone aldosterone and proinflammatory cytokines while preserving endotoxin-induced release of anti-inflammatory corticosterone (Sánchez-Lemus et al, 2008). This indicates that the overall peripheral effect of ARB pretreatment is to shift the balance in favor of anti-inflammatory factors in the circulation during the initial phase of the inflammatory response.

The ARB significantly reduced the inflammation-induced mRNA expression of proinflammatory cytokines and their receptors in all brain areas examined, a widespread effect not only restricted to previously identified inflammation target areas, such as the PVN and SFO, but also present in brain structures expressing $\mathrm{AT}_{1}$ receptors (Jöhren et al, 1995; Lenkei et al, 1998) and involved in the regulation of emotion, cognition, and memory, such as the ventromedial prefrontal cortex, central nucleus of the amygdala, and CA1 subdivision of the hippocampus (McEwen, 2008).

$\mathrm{AT}_{1}$ receptor blockade reduced inflammation-induced activation of transcription factors regulating expression of multiple inflammatory genes (Licinio and Wong, 1997; Quan and Banks, 2007), including c-Fos and FosB, members of the activator protein-1 (AP-1) transcription family, and $\mathrm{NF}-\kappa \mathrm{B}$, visualized by $\mathrm{I} \kappa \mathrm{B}-\alpha$ induction, which parallels NF- $\kappa \mathrm{B}$ activation (Beg et al, 1993; Figure 8). This explains 


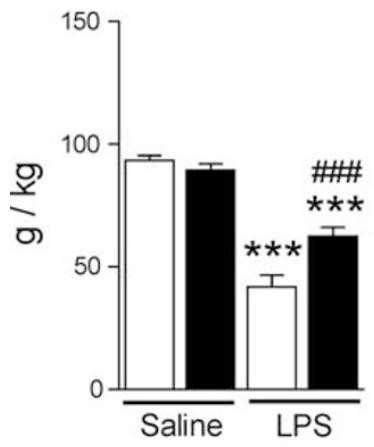

b

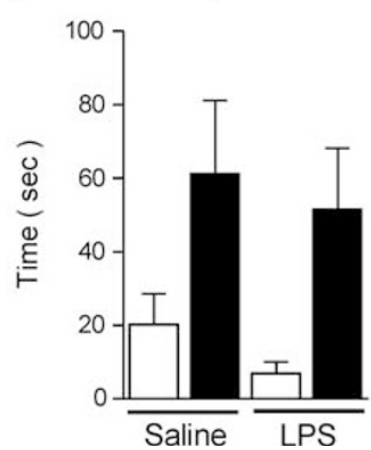

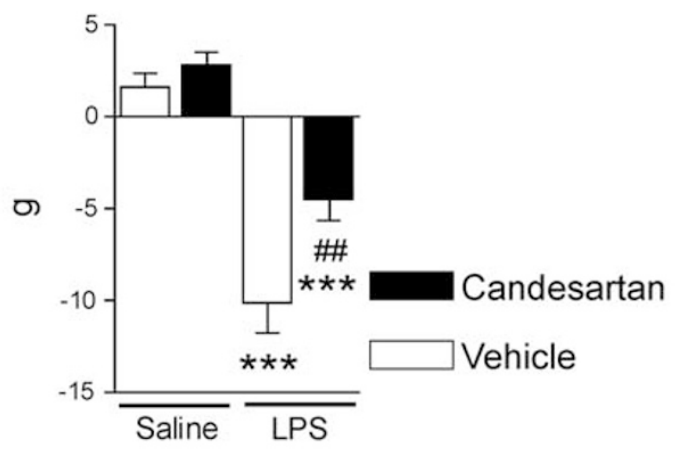

Open Arm Entries

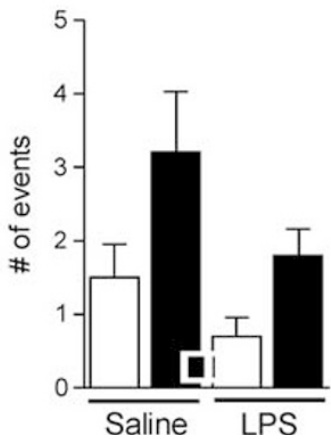

Open Arm Entries Ratio

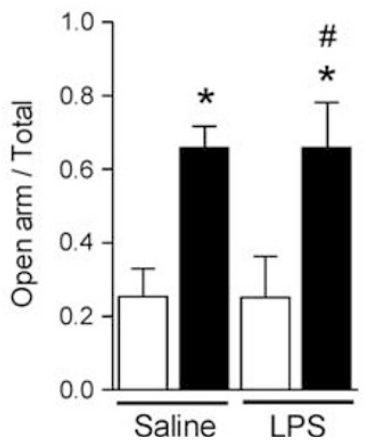

Figure 7 Candesartan ameliorates LPS-induced anorexia and weight loss in Wistar Hannover rats, and decreases anxiety-like behavior in SHRs. (a) Shortterm candesartan and LPS were administered as described in Materials and Methods. Food consumption and body weight change were measured the day after LPS injection $(n=8-10)$. (b) Short-term candesartan and LPS were administered to SHRs as described in Materials and Methods. At $3 \mathrm{~h}$ after LPS injection, the rats were tested on an elevated plus maze for $5 \mathrm{~min}$ as described in Materials and Methods $(n=9-10)$. Data are expressed as means \pm SEM.

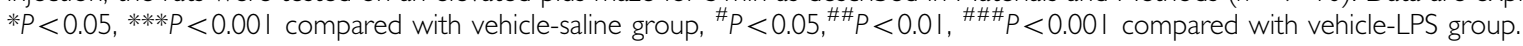

the inhibition not only of proinflammatory cytokines but also of enzymes, such as iNOS and COX-2, regulating production of inflammatory signals $\mathrm{NO}$ and prostanoids, such as $\mathrm{PGE}_{2}$ (Figure 8). Our results are consistent with the established role of NF- $\kappa \mathrm{B}$ as a major mediator of LPS effects in the brain (Pan et al, 2010), contradicting earlier observations reporting that intracerebral administration of LPS did not activate NF- $\kappa$ B or AP- 1 in the brain (Watanabe et al, 2006).

Inhibition of gene expression of the $\mathrm{PGE}_{2}$ receptor $\mathrm{EP} 4$ and many cytokine receptors reveals that the ARB limits not only the production of inflammatory mediators but also the capacity of the cellular targets to respond to inflammation. These results suggest the possibility that ARBs may also protect brain cells from other kinds of injury. For example, the EP4 receptor has been linked to production of amyloid $\beta$ peptides characteristic of Alzheimer's disease (Hoshino et al, 2009), suggesting that its repression may be therapeutically beneficial.

ARBs exert brain anti-inflammatory effects by a number of parallel mechanisms (Figure 8). By decreasing circulating proinflammatory cytokines (present results; Sánchez-Lemus et al, 2008, 2009a, b), transcription of cytokine receptors, TLR4 (Dasu et al, 2009), and in particular CD14 (present results) in target areas, ARBs may reduce the capacity of the brain to recognize and respond to inflammatory factors evoked by the innate immune response. Our data suggest that the potent proinflammatory effects of Ang II in the periphery (Savoia and Schiffrin, 2007) and the brain (Zhou et al, 2005) involve sharing signal transduction pathways with inflammatory stimuli (Savoia and Schiffrin, 2007). Inflammation enhances brain $\mathrm{AT}_{1}$ receptor transcription in the PVN and directly in cultured cerebellar granule cells, suggesting a clear link between inflammatory stimuli and Ang II. A reduction of Ang II-induced inflammatory cascades is an additional mechanism explaining the overall central anti-inflammatory effects of $\mathrm{AT}_{1}$ receptor blockade.

Although the systemic administration of candesartan studied here effectively blocks both peripheral and brain $\mathrm{AT}_{1}$ receptors and the effects of centrally administered Ang II (Nishimura et al, 2000; Seltzer et al, 2004), we cannot conclusively determine the relative role of central and peripheral $\mathrm{AT}_{1}$ receptors in our model. To demonstrate that the changes observed in the brain may not exclusively depend on cross-system interactions, we studied the effects of LPS and $\mathrm{AT}_{1}$ receptor blockade at the cellular level. We used primary cultures of isolated brain neurons, microglia, and endothelial cells, primary targets for circulating inflammatory cytokines and LPS (Quan and Banks, 2007). $\mathrm{AT}_{1}$ receptor blockade exerted direct anti-inflammatory effects in a cerebellar cell culture highly enriched in granule cell neurons (Gao et al, 1995) and constitutively expressing $\mathrm{AT}_{1 \mathrm{~A}}$ receptors, $\mathrm{CD} 14$, and TLR4. In addition, $\mathrm{AT}_{1}$ receptor blockade reduced inflammation in cultured 


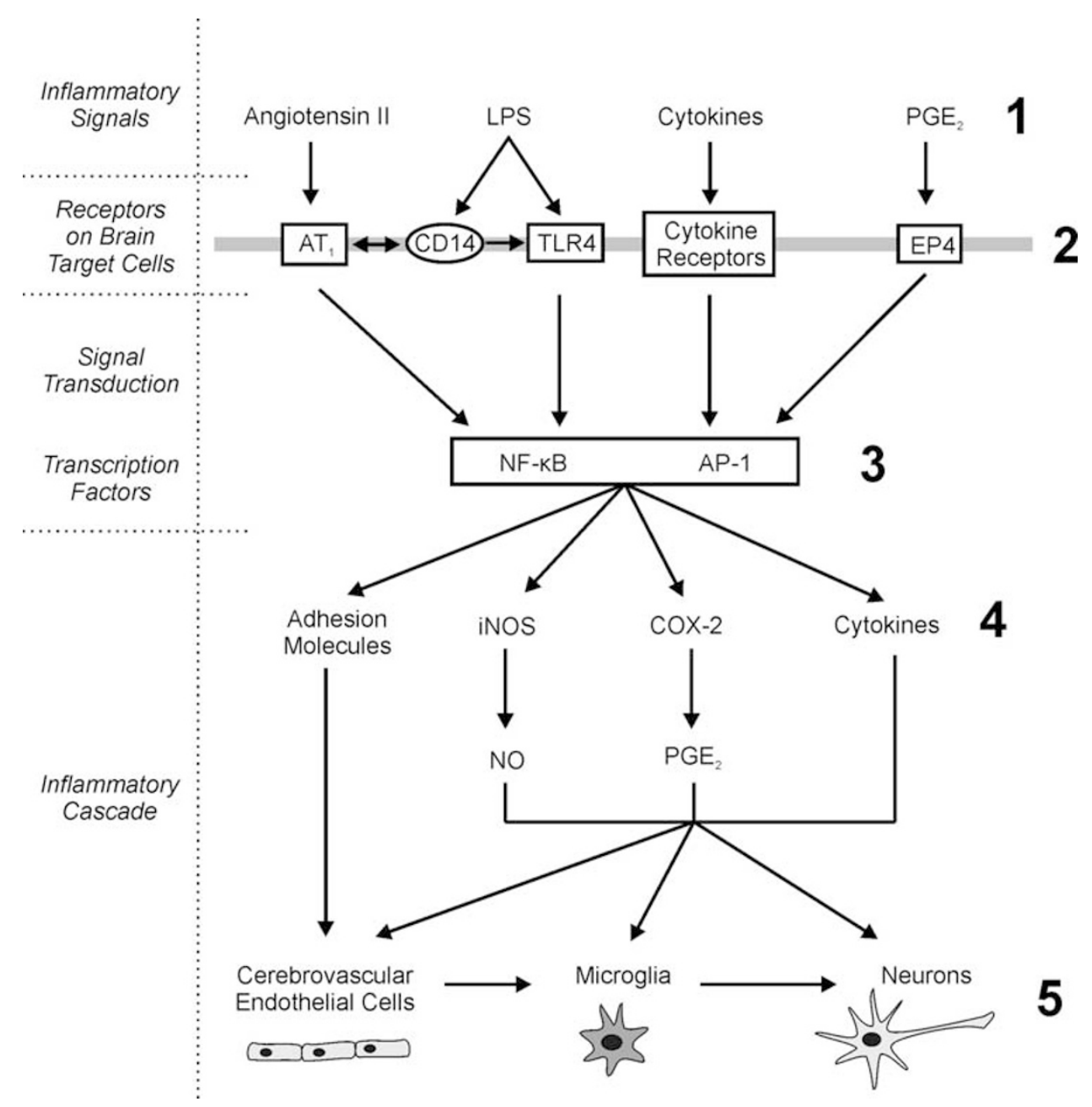

Figure 8 Angiotensin II and inflammatory signal pathways in the brain. AT, receptor activity is an important factor during brain inflammation. Angiotensin II and inflammatory stimuli interact, enhancing several common downstream signaling pathways. ARBs reduce inflammatory induction of peripheral cytokines and their release to the circulation (I). Inflammatory signals (I) induce transcription of angiotensin II AT, CDI 4, cytokine, and EP4 receptors in brain target cells (2). Angiotensin II AT, receptor blockade eliminates angiotensin II-stimulated downstream signaling and represses downstream transcription factors NF$\kappa \mathrm{B}$ and AP-I (3). This limits inflammation-induced increase in brain inflammatory cascades: proinflammatory cytokines, cytokine and prostanoid receptors, inducible enzymes leading to $\mathrm{PGE}_{2}$ and $\mathrm{NO}$ overproduction and adhesion molecules (4). In turn, this reduces microglia activation and neuronal injury in brain parenchyma (5) limiting the brain inflammatory reaction.

cerebral microvascular endothelial cells. These cells are involved in inflammatory leukocyte infiltration into the brain (Zhou et al, 2006; Man et al, 2007). Blockade of $\mathrm{AT}_{1}$ receptors in cerebrovascular endothelial cells (Zhou et al, 2006) may reduce Ang II-mediated increase in blood brain barrier permeability and peripheral proinflammatory cell migration to the vasculature or brain parenchyma, explaining the beneficial effects of ARBs ameliorating brain inflammation in hypertension and diabetes (FleegalDeMotta et al, 2009). This anti-inflammatory activity is most likely sequentially replicated in adjacent neighboring microglia and neuronal cells. Stimulation of inflammatory cascades at endothelial target cells is followed by activation of microglia (Figure 8), the central resident immune cells (Henry et al, 2009), leading to induction of additional inflammatory cascades and ultimately producing, if unchecked, glial and neuronal damage (Henry et al, 2009). In particular, microglia activation increases LPS-induced neurotoxicity and consequently, the reduction of the proinflammatory microglia response enhances neuronal survival (Liu et al, 2010). We demonstrate here that the ARB candesartan inhibited the microglia activation marker CD40 and IL-1 $\beta$ mRNA expression and release in an enriched microglia cells culture. This is consistent with our finding of decreased microglia activation in vivo as a result of systemic candesartan administration, and it is in agreement with the previous observation of inhibition of inflammation-induced microglia activation, in vitro, by the ARB losartan (Miyoshi et al, 2008). Reduction of microglia activation might be another mechanism of ARBs promoting neuroprotection.

We report here direct anti-inflammatory effects of candesartan in LPS brain target cells. Our results do not exclude a major influence of peripheral anti-inflammatory effects in the candesartan-induced amelioration of brain inflammation. However, the in vitro experiments demonstrate that candesartan is able to directly and significantly reduce inflammation in LPS target cells in the brain. This suggests that direct central effects of candesartan may have a role in the amelioration of brain inflammation, which follows systemic administration of the ARB. 
The central anti-inflammatory effects of the ARB have behavioral correlates as we demonstrate here. Candesartan reduced the acute sickness behavior produced by LPS, in particular its anorexic effect leading to acute weight loss (Konsman and Dantzer, 2001). In addition, candesartan ameliorated anxiety-like behavior in SHR, a strain with known hypersensitivity to stress and to LPS administration (Kvetnansky et al, 1979; Sirén et al, 1992). These effects were observed in both control and LPS-treated animals, indicating general anxiolytic properties that may be independent on the effect of LPS. Anxiolytic effects have been previously reported in normotensive rats exposed to prolonged treatment with candesartan (Saavedra et al, 2006), and both normotensive and hypertensive rats after acute treatment with another ARB, losartan (Srinivasan et al, 2003). Acute anxiolytic effects observed $5 \mathrm{~min}$ after intracerebroventricular injection of losartan (Kulakowska et al, 1996) further point to the direct involvement of brain Ang II $\mathrm{AT}_{1}$ receptors in these behavioral changes.

In conclusion, our results demonstrate that direct brain inflammation, and peripheral inflammation affecting the brain are, to a significant degree, dependent on full $\mathrm{AT}_{1}$ receptor function. ARBs limit, but do not eliminate the response of the brain to inflammatory signals. This is an important finding, as responding to inflammation is necessary to maintain and restore homeostasis, and pathological conditions may further develop as a consequence of unrestricted inflammation (Dantzer et al, 2008).

This report provides a basis to support recent findings in clinically relevant neuroinflammatory models. For example, brain RAS is upregulated in an animal model of multiple sclerosis, the experimental autoimmune encephalomyelitis, and ARBs ameliorate the characteristic paralysis and infiltration of inflammatory TH1 and TH17 cells in this model (Platten et al, 2009). Further evidence indicates that $A R B s$ protect the brain from injuries promoting parenchymal inflammation and neuronal damage, such as irradiation-induced brain inflammation (Jenrow et al, 2010) and inflammation-induced dopaminergic neuronal death (Mertens et al, 2010).

Our results have major clinical significance. Excessive, uncontrolled inflammation is recognized as a major factor contributing to many psychiatric and neurological diseases, including but not limited to major depression and anxiety disorders, bipolar illness, schizophrenia, and neurodegenerative diseases such as Parkinson's and Alzheimer's disease (Dantzer et al, 2008; Doorduin et al, 2009; Glass et al, 2010; Fassbender et al, 2004; Hope et al, 2009; Miller et al, 2009). ARBs are compounds with excellent margin of safety, successfully used for years to treat not only increased systemic blood pressure but also to ameliorate the profound inflammatory component of peripheral cardiovascular disease and diabetes (Savoia and Schiffrin, 2007). We have previously found that ARBs reverse the cerebrovascular inflammation characteristic of genetic hypertension in an animal model (Ando et al, 2004; Zhou et al, 2005), and we demonstrate here that these compounds are very effective anti-inflammatory agents in the brain parenchyma of normotensive rats.

Our proposal to test ARBs for the therapy of inflammatory diseases of the brain is sustained by substantial clinical evidence indicating that $\mathrm{ARBs}$ are neuroprotective in humans (Anderson, 2010). ARBs prevent and ameliorate stroke in hypertensive patients to a greater degree than other similarly potent anti-hypertensive medications, in part as a consequence of effects beyond blood pressure control (Anderson, 2010). ARBs protect cognition both in hypertensive patients and in the elderly, significantly reducing the incidence and progression of Alzheimer's disease (Li et al, 2010). Other studies reported improvement in the quality of life, and amelioration of depression and stress (Phillips and de Oliveira, 2008). ARBs may represent a novel and safe approach for the treatment of acute and chronic neuropsychiatric disorders of increasing prevalence and socioeconomic impact where inflammation has a significant role.

\section{ACKNOWLEDGEMENTS}

This study was supported by the Division of Intramural Research Programs, National Institute of Mental Health, Department of Health and Human Services, USA. Dr Honda was supported by the Japan Society for the Promotion of Science Research Fellowship for Japanese Biomedical and Behavioral Researchers at NIH. We thank Astra-Zeneca, Mölndal, Sweden, for the supply of candesartan, and to Andrés Negro Vilar MD, PhD, for his helpful comments and suggestions during the preparation of the manuscript.

\section{DISCLOSURE}

The authors declare no conflict of interest.

\section{REFERENCES}

Anderson C (2010). More direct evidence of potential neuroprotective benefits of Angiotensin receptor blockers. Hypertension 28: 429.

Ando H, Zhou J, Macova M, Imboden H, Saavedra JM (2004). Angiotensin II AT1 receptor blockade reverses pathological hypertrophy and inflammation in brain microvessels of spontaneously hypertensive rats. Stroke 35: 1726-1731.

Beg AA, Finco TS, Nantermet PV, Baldwin Jr AS (1993). Tumor necrosis factor and interleukin-1 lead to phosphorylation and

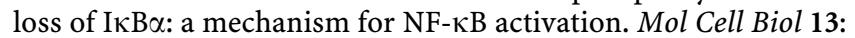
3301-3310.

Benicky J, Sánchez-Lemus E, Pavel J, Saavedra JM (2009). Anti-inflammatory effects of angiotensin receptor blockers in the brain and the periphery. Cell Mol Neurobiol 29: 781-792.

Dantzer R, O'Connor JC, Freund GG, Johnson RW, Kelley KW (2008). From inflammation to sickness and depression: when the immune system subjugates the brain. Nat Rev Neurosci 9: 46-57.

Dasu MR, Riosvelasco AC, Jialal I (2009). Candesartan inhibits toll-like receptor expression and activity both in vitro and in vivo. Atherosclerosis 202: 76-83.

Doorduin J, de Vries EF, Willemsen AT, de Groot JC, Dierckx RA, Klein HC (2009). Neuroinflammation in schizophrenia-related psychosis: a PET study. J Nucl Med 50: 1801-1807.

Fassbender K, Walter S, Kühl S, Landmann R, Ishii K, Bertsch T et al (2004). The LPS receptor (CD14) links innate immunity with Alzheimer's disease. FASEB J 18: 203-205.

Fleegal-DeMotta MA, Doghu S, Banks WA (2009). Angiotensin II modulates BBB permeability via activation of the AT(1) receptor in brain endothelial cells. J Cereb Blood Flow Metab 29: 640-647.

Gao X-M, Margolis RL, Leeds P, Hough C, Post RM, Chuang DM (1995). Carbamazepine induction of apoptosis in cultured 
cerebellar neurons: effects of N-methyl-D-aspartate, aurintricarboxylic acid and cycloheximide. Brain Res 703: 63-71.

Glass CK, Saijo K, Winner B, Marchetto MC, Gage FH (2010). Mechanisms underlying inflammation in neurodegeneration. Cell 140: 918-934.

Giulian D, Baker TJ (1986). Characterization of ameboid microglia isolated from developing mammalian brain. J Neurosci 6: 2163-2178.

Henry CJ, Huang Y, Wynne AM, Godbout JP (2009). Peripheral lipopolysaccharide (LPS) challenge promotes microglial hyperactivity in aged mice that is associated with exaggerated induction of both pro-inflammatory IL-1b and anti-inflammatory IL-10 cytokines. Brain Behav Immun 23: 309-317.

Hope S, Melle I, Aukrust P, Steen NE, Birkenaes AB, Lorentzen S et al (2009). Similar immune profile in bipolar disorder and schizophrenia: selective increase in soluble tumor necrosis factor receptor I and von Willebrand factor. Bipolar Disord 11: 726-734.

Hoshino T, Namba T, Takehara M, Nakaya T, Sugimoto Y, Araki W et al (2009). Prostaglandin E2 stimulates the production of amyloid-beta peptides through internalization of the EP4 receptor. J Biol Chem 284: 18493-18502.

Jenrow KA, Brown SL, Liu J, Kolozsvary A, Lapanowski K, Kim JH (2010). Ramipril mitigates radiation-induced impairment of neurogenesis in the rat dentate gyrus. Radiat Oncol 5: 6.

Johren O, Inagami T, Saavedra JM (1995). AT1A, AT1B, and AT2 angiotensin II receptor subtype gene expression in rat brain. Neuroreport 6: 2549-2552.

Kim YS, Honkaniemi J, Sharp FR, Tauber MG (2004). Expression of proinflammatory cytokines tumor necrosis factor- $\alpha$ and interleukin- $1 \beta$ in the brain during experimental group $B$ streptococcal meningitis. Brain Res Mol Brain Res 128: 95-102.

Konsman JP, Dantzer R (2001). How the immune and nervous system interact during disease-associated anorexia. Nutrition 17: 664-668.

Kulakowska A, Karwowska W, Wisniewski K, Braszko JJ (1996). Losartan influences behavioural effects of angiotensin II in rats. Pharmacol Res 34: 109-115.

Kvetnansky R, McCarty R, Thoa NB, Lake CR, Kopin IJ (1979). Sympatho-adrenal responses of spontaneously hypertensive rats to immobilization stress. Am J Physiol 236: H457-H462.

Larrayoz IM, Pang T, Benicky J, Pavel J, Sánchez-Lemus E, Saavedra JM (2009). Candesartan reduces the innate immune response to lipopolysaccharide in human monocytes. J Hypertens 27: 2365-2376.

Lenkei Z, Palkovits M, Corvol P, Llorens-Cortes C (1998). Distribution of angiotensin type-1 receptor messenger RNA expression in the adult rat brain. Neuroscience 82: 827-841.

Li NC, Lee A, Whitmer RA, Kivipelto M, Lawler E, Kazis LE et al (2010). Use of angiotensin receptor blockers and risk of dementia in a predominantly male population: prospective cohort analysis. BMJ 340: b5465.

Licinio J, Wong M-L (1997). Pathways and mechanisms for cytokine signaling of the central nervous system. J Clin Invest 100: 2941-2947.

Liu Y, Lo YC, Qian L, Crews FT, Wilson B, Chen HL et al (2010). Verapamil protects dopaminergic neuron damage through a novel anti-inflammatory mechanism by inhibition of microglial activation. Neuropharmacology, doi:10.1016/j.neuropharm 2010.10.002 (in press).

Man S, Ubogu EE, Ransohoff RM (2007). Inflammatory cell migration into the central nervous system: a few new twists on an old tale. Brain Pathol 17: 243-250.

Maynard CL, Weaver CT (2008). Diversity in the contribution of interleukin-10 to T-cell-mediated immune regulation. Immunol Rev 226: 219-233.

McEwen BS (2008). Central effects of stress hormones in health and disease: understanding the protective and damaging effects of stress and stress mediators. Eur J Pharmacol 583: 174-185.
Mertens B, Vanderheyden P, Michotte Y, Sarre S (2010). The role of the central renin-angiotensin system in Parkinson's disease. J Renin Angiotensin Aldosterone Syst 11: 49-56.

Miller AH, Maletic V, Raison CL (2009). Inflammation and its discontents: the role of cytokines in the pathophysiology of major depression. Biol Psych 65: 732-741.

Milligan CE, Cunningham TJ, Levitt P (1991). Differential immunochemical markers reveal the normal distribution of brain macrophages and microglia in the developing rat brain. J Comp Neurol 314: 125-135.

Miyoshi M, Miyano K, Moriyama N, Taniguchi M, Watanabe T (2008). Angiotensin type 1 receptor antagonist inhibits lipopolysaccharide-induced stimulation of rat microglial cells by suppressing nuclear factor $\mathrm{jB}$ and activator protein-1 activation. Eur J Neurosci 27: 343-351.

Nakagawa S, Deli MA, Kawaguchi H, Schimizudani T, Shimono T, Kittel A et al (2009). A new blood-brain barrier model using primary rat brain endothelial cells, pericytes and astrocytes. Neurochem Int 54: 253-263.

Nimmo AJ, Vink R (2009). Recent patents in CNS drug discovery: the management of inflammation in the central nervous system. Recent Pat CNS Drug Discov 4: 86-95.

Nishimura Y, Ito T, Hoe K, Saavedra JM (2000). Chronic peripheral administration of the angiotensin II $\mathrm{AT}(1)$ receptor antagonist candesartan blocks brain AT(1) receptors. Brain Res 871: 29-38.

Pan W, Yu C, Hsuchou H, Kastin AJ (2010). The role of cerebral vascular NFkappaB in LPS-induced inflammation: differential regulation of efflux transporter and transporting cytokine receptors. Cell Physiol Biochem 25: 623-630.

Paxinos G, Watson C (1998). The Rat Brain in Stereotaxic Coordinates, 4th edn. Academic Press: New York.

Phillips MI, de Oliveira EM (2008). Brain renin angiotensin in disease. J Mol Med 86: 715-722.

Platten M, Youssef S, Hur EM, Ho PP, Han MH, Lanz TV et al (2009). Blocking angiotensin-converting enzyme induces potent regulatory $\mathrm{T}$ cells and modulates $\mathrm{TH} 1-$ and TH17-mediated autoimmunity. Proc Nat Acad Sci USA 106: 14948-14953.

Popovich PG, Wei P, Stokes BT (1997). Cellular inflammatory response after spinal cord injury in Sprague-Dawley and Lewis rats. J Comp Neurol 377: 443-464.

Quan N, Banks WA (2007). Brain-immune communication pathways. Brain Behav Immun 21: 727-735.

Rivest S (2009). Regulation of innate immune responses in the brain. Nat Rev Immunol 9: 429-439.

Ruifrok AC, Johnston DA (2001). Quantification of histochemical staining by color deconvolution. Anal Quant Cytol Histol 23: 291-299.

Russell VA (2003). Dopamine hypofunction possibly results from a defect in glutamate-stimulated release of dopamine in the nucleus accumbens shell of a rat model for attention deficit hyperactivity disorder - the spontaneously hypertensive rat. Neurosci Biobehav Rev 27: 671-682.

Saavedra JM (1992). Brain and pituitary angiotensin. Endocr Rev 13: $329-380$.

Saavedra JM, Armando I, Bregonzio C, Juorio A, Macova M, Pavel J et al (2006). A centrally acting, anxiolytic angiotensin II AT1 receptor antagonist prevents the isolation stress-induced decrease in cortical CRF1 receptor and benzodiazepine binding. Neuropsychopharm 31: 1123-1134.

Sánchez-Lemus E, Benicky J, Pavel J, Larrayoz IM, Zhou J, Baliova $\mathrm{M}$ et al (2009a). Angiotensin II AT1 blockade reduces the lipopolysaccharide-induced innate immune response in rat spleen. Am J Physiol Regul Integr Comp Physiol 296: R1376-R1384.

Sánchez-Lemus E, Benicky J, Pavel J, Saavedra JM (2009b). In vivo angiotensin II $\mathrm{AT}(1)$ receptor blockade selectively inhibits LPS-induced innate immune response and ACTH release in rat pituitary gland. Brain Behav Immun 23: 945-957. 
Sánchez-Lemus E, Murakami Y, Larrayoz-Roldan IM, Moughamian AJ, Pavel J, Nishioku T et al (2008). Angiotensin II AT1 receptor blockade decreases lipopolysaccharide-induced inflammation in the rat adrenal gland. Endocrinology 149: 5177-5188.

Savoia C, Schiffrin EL (2007). Vascular inflammation in hypertension and diabetes: molecular mechanisms and therapeutic interventions. Clin Sci 112: 375-384.

Schmerbach K, Schefe JH, Krikov M, Müller S, Villringer A, Kintscher $\mathrm{U}$ et al (2008). Comparison between single and combined treatment with candesartan and pioglitazone following transient focal ischemia in rat brain. Brain Res 1208: 225-233.

Seeger H, Lippert C, Wallwiener D, Mueck AO (2001). Valsartan and candesartan can inhibit deteriorating effects of angiotensin II on coronary endothelial function. J Renin Angiotensin Aldosterone Syst 2: 141-143.

Seltzer A, Bregonzio C, Armando I, Baiardi G, Saavedra JM (2004). Oral administration of an AT1 receptor antagonist prevents the central effects of angiotensin II in spontaneously hypertensive rats. Brain Res 1028: 9-18.

Sirén AL, Heldman E, Doron D, Lysko PG, Yue TL, Liu Y et al. (1992). Release of proinflammatory and prothrombotic mediators in the brain and peripheral circulation in spontaneously hypertensive and normotensive Wistar-Kyoto rats. Stroke 23: 1643-1650.

Srinivasan J, Suresh B, Ramanathan M (2003). Differential anxiolytic effect of enalapril and losartan in normotensive and renal hypertensive rats. Physiol Behavior 78: 585-591.
Tsutsumi K, Saavedra JM (1991). Characterization and development of angiotensin II receptor subtypes (AT1 and AT2) in rat brain. Am J Physiol 261: R209-R216.

Vaisanen J, Ihalainen J, Tanila H, Castrén E (2004). Effects of NMDA-receptor antagonist treatment on c-fos expression in rat brain areas implicated in schizophrenia. Cell Mol Neurobiol 24: 769-780.

Watanabe K, Taniguchi M, Miyoshi M, Shimizu H, Imoto T, Sato K et al (2006). Effects of central injection of angiotensinconverting-enzyme inhibitor and Angiotensin type 1 receptor antagonist on the brain NF-kappaB and AP-1 activities of rats given LPS. Peptides 27: 1538-1546.

Weinberg AJ, Zappe DH, Ashton AA, Weinberg MS (2004). Safety and tolerability of high-dose angiotensin receptor blocker therapy in patients with chronic kidney disease: a pilot study. Am J Nephrol 24: 340-345.

Yong VW, Rivest S (2009). Taking advantage of the systemic immune system to cure brain diseases. Neuron 64: 55-60.

Zhou J, Ando H, Macova M, Dou J, Saavedra JM (2005). Angiotensin II $\mathrm{AT}_{1}$ receptor blockade abolishes brain microvascular inflammation and heat shock protein responses in hypertensive rats. J Cereb Blood Flow Metab 25: 878-886.

Zhou J, Pavel J, Macova M, Yu ZX, Imboden H, Ge L et al (2006). $\mathrm{AT}_{1}$ receptor blockade regulates the local angiotensin II system in cerebral microvessels from spontaneously hypertensive rats. Stroke 37: 1271-1276.

Supplementary Information accompanies the paper on the Neuropsychopharmacology website (http://www.nature.com/npp) 